\title{
THE ROLE OF NATURA 2000 NETWORK IN PROTECTING THE ORCHID FLORA OF EAST MACEDONIA (NE GREECE)
}

\author{
SPYROS TSIFTSIS*
}

\begin{abstract}
Department of Forest and Natural Environment Sciences, International Hellenic University, GR-66132 Drama, Greece * Corresponding author: stsiftsis@for.ihu.gr
\end{abstract}

\begin{abstract}
East Macedonia (northeast Greece) is a relatively small part of Greece, where a considerable number of orchid taxa occurs. Some of these orchids can only be found there and this fact makes the specific area of Greece unique. In this study, an up-to date database of orchid records was used to assess the effectiveness of the existing Natura 2000 network. Specifically, the effectiveness of the Natura 2000 network was evaluated by identifying the number of orchids whose distribution is overlapping to a lesser or greater extent with the network, which chorological categories are included/excluded from it, and whether the rare and threatened orchid taxa are adequately distributed within that. Out of the 73 orchid taxa recorded in East Macedonia so far, 14 taxa are exclusively distributed outside the Natura 2000 network. Specifically, the Natura 2000 network is not overlapped with a number of Balkan and Mediterranean orchid taxa, which are only sparsely found in East Macedonia. Moreover, most of the orchid taxa that have been classified in the threat categories of the IUCN are distributed within the Natura 2000 network of East Macedonia, and specifically, some of the most threatened ones are almost exclusively distributed within that network. Consequently, although the Natura 2000 network is not congruent with the distribution of a number of species of southern origin, which are widely distributed elsewhere in Greece, it can conserve important floristic elements of Greece, which are orchid taxa of northern or central European origin.
\end{abstract}

Keywords: conservation; East Mediterranean; Orchidaceae; threatened species

\section{Introduction}

The human impact and activities over the past few decades have caused serious declines in organisms all around the world, and as a result, governments have signed environmental agreements to reverse these declines (Rogalla von Bieberstein et al. 2019). Globally, the Convention on Biological Diversity to which 196 countries are contracting parties, is one of the most important agreements, whose Aichi Biodiversity Targets referred to its Strategic Plan for Biodiversity 2011-2020 (Decision $\mathrm{X} / 2$ ) include the protection of $17 \%$ of the earth and $10 \%$ of the oceans (strategic goal C: target 11). Thus, all around the world, protected areas, such as national parks and nature reserves, constitute a key strategy for conserving biodiversity (Geldmann et al. 2019).

In Europe, the 27 member states of the European Union have established a network of protected areas called "Natura 2000 network" by applying two Directives; the Birds (Directive 79/409/EEC, which was amended by the Directive 2009/147/EC) and the Habitats (Directive 92/43/EEC) Directive (European Commission 2020). The Natura 2000 network in Europe covers more than $18 \%$ of the EU's land area and more than $8 \%$ of its marine territory, and it is considered the largest coordinated network of protected areas in the world. Conservation of plant species and/or habitats is subject to the Habitats Directive (Directive 92/43/EEC) through the establishment of a network of Special Areas of Conservation (SACs). In Greece, this network is composed of 241 sites (SACs), covering $21.27 \%$ of the terrestrial area of the country, which is among the highest among the European countries.
Although networks of protected areas are considered to be the most important measures that governments take to conserve biodiversity, the effectiveness of these networks is still uncertain in several cases (Watson et al. 2014; Joppa et al. 2016). Looking at the geographical location of the Special Areas of Conservation of the Natura 2000 network in Greece, one can identify that most of these have been established in high-altitude areas. This could be attributed to two different reasons: (a) the high species diversity of the mountainous areas in Greece, and (b) the rather low human activities in these areas compared to areas of lower altitudes, where natural habitats are more degraded. Based on this, it is unclear, whether SACs in Greece can adequately conserve populations of specific subsets or groups of plant species. For example, the Natura 2000 network in the Peloponnese was only partly congruent with a theoretical network of areas for the protection of the endemic flora of the Peloponnese (Trigas et al. 2012). However, this study is not the only one, where Natura 2000 network did not fully overlap with the distribution of all the target plant species. Similar results presented by Dimitrakopoulos et al. (2004), who worked with the plant species of Crete, and by Tsiftsis et al. (2009; 2011), who explored the effectiveness of the Natura 2000 network using the orchids of a subarea of East Macedonia and Crete, respectively.

The orchid family is characterized by a complex biology and an especially high speciation rate, but many orchid taxa are at the verge of extinction (Swarts and Dixon 2009). These characteristics make orchids an important group in biological conservation and because of the threats and danger that many orchids face they are protected in several countries (in Greece, as well) by 




Fig. 1 Distribution of the orchid taxa of Greece (red line represents the limit among the northeast and northcentral floristic regions of Greece).

legislation. Under general legislation, many orchid taxa are protected by the Directive 92/43/EEC (21-5-1992), whereas the whole family of Orchidaceae is included in the three Appendices of CITES (Convention on International Trade in Endangered Species of Wild Fauna and Flora).

Greece is especially rich in orchids (193 orchid taxa have been recorded so far) and one of the most orchid rich countries in Europe (Delforge 2006; Tsiftsis and Antonopoulos 2017). However, as in all plant families, orchids are not evenly distributed throughout Greece (Tsiftsis et al. 2019). As it can be seen in Fig. 1, northeast Greece is relatively poor in number of orchid taxa compared to the other areas of Greece. East Macedonia constitutes an exception to this general trend, as the specific area hosts quite a large number of orchid taxa. Based on Tsiftsis et al. (2007), 62 orchid taxa were found in East Macedonia in 2007 and additional orchid taxa were recorded later (e.g. Gymnadenia odoratissima: Lafranchis and Sfikas 2009; Pseudorchis albida: Tsiftsis and Antonopoulos 2011). East Macedonia unique in Greece, because specific orchid taxa, some of which cannot be found elsewhere in the country, have been recorded in the high-altitude mountains. Under this perspective, the reassessment of the effectiveness of the Natura 2000 network in the area is desirable.

It is well-known that the effectiveness of a network of protected areas in conserving a set of target species is influenced (a) by the degree of representation of the target species within these areas, and (b) the management actions that will be focused on these species (González-Maya et al. 2015; Geldmann et al. 2019; Neugarten et al. 2020). Compared to the database used by Tsiftsis et al. (2009), the database of orchid records of East Macedonia was enriched by additional species distribution data obtained after 2009. Thus, the queries I tried to answer were:

a) How effectively is the Natura 2000 network conserving the orchid flora of East Macedonia in the light of the new data?

b) Which chorological categories of orchid taxa does the Natura 2000 network conserve?

c) What is the significance of the Natura 2000 network of East Macedonia in conserving rare and threatened orchid taxa of Greece?

\section{Material and Methods}

The study area comprises the whole of East Macedonia (longitude $23^{\circ} 17^{\prime}$ to $24^{\circ} 54^{\prime} \mathrm{E}$, latitude $40^{\circ} 38^{\prime}$ to $41^{\circ} 34^{\prime} \mathrm{N}$ )

Table 1 Special Areas of Conservation in East Macedonia (NE Greece).

\begin{tabular}{|r|c|r|l|}
\hline & $\begin{array}{c}\text { Special Areas } \\
\text { of Conservation }\end{array}$ & Area (ha) & Official name \\
\hline 1 & GR1260002 & $1,297.10$ & Ekvoles Potamou Strymona \\
\hline 2 & GR1120003 & $3,491.99$ & Oros Chaintou - Koula and Gyro Koryfes \\
\hline 3 & GR1120005 & $2,335.87$ & Aisthitiko Dasos Nestou \\
\hline 4 & GR1140001 & $1,090.05$ & Dasos Fraktou \\
\hline 5 & GR1140002 & $6,715.45$ & Rodopi (Simyda) \\
\hline 6 & GR1140003 & $7,447.10$ & Periochi Elatia, Pyramis Koutra \\
\hline 7 & GR1140004 & $9,845.62$ & Koryfes Orous Falakro \\
\hline 8 & GR1150005 & $10,345.47$ & Koryfes Orous Pangaio \\
\hline 9 & GR1150010 & $22,484.64$ & Delta Nestou kai Limnothalasses Keramotis - Evryteri Periochi kai Paraktia Zoni \\
\hline 10 & GR1220003 & $2,905.16$ & Stena Rentinas - Evryteri Periochi Spilaio Drakotrypa - Spilaio Lakkia kai Rema Neromana \\
\hline 11 & GR1260003 & 327.29 & Ai Giannis - Eptamyloi \\
\hline 12 & GR1260004 & $23,288.69$ & Koryfes Orous Menoikion - Oros Kouskouras - Ypsoma \\
\hline 13 & GR1260005 & $4,871.04$ & Koryfes Orous Orvilos \\
\hline 14 & GR1260007 & $6,799.47$ & Ori Vrondous - Lailias - Epimikes - Spilaia Zesta Nera kai Katarrakton \\
\hline
\end{tabular}


(Fig. 2), including all the high mountains of North-East Greece (Mts Menikion, Orvilos, Falakron, Pangeon, Vrondous, Lekani, Simvolo, Kerdilion and Rodopi). The area comprises of fourteen Special Areas of Conservation (SAC) of the European Ecological Network Natu-

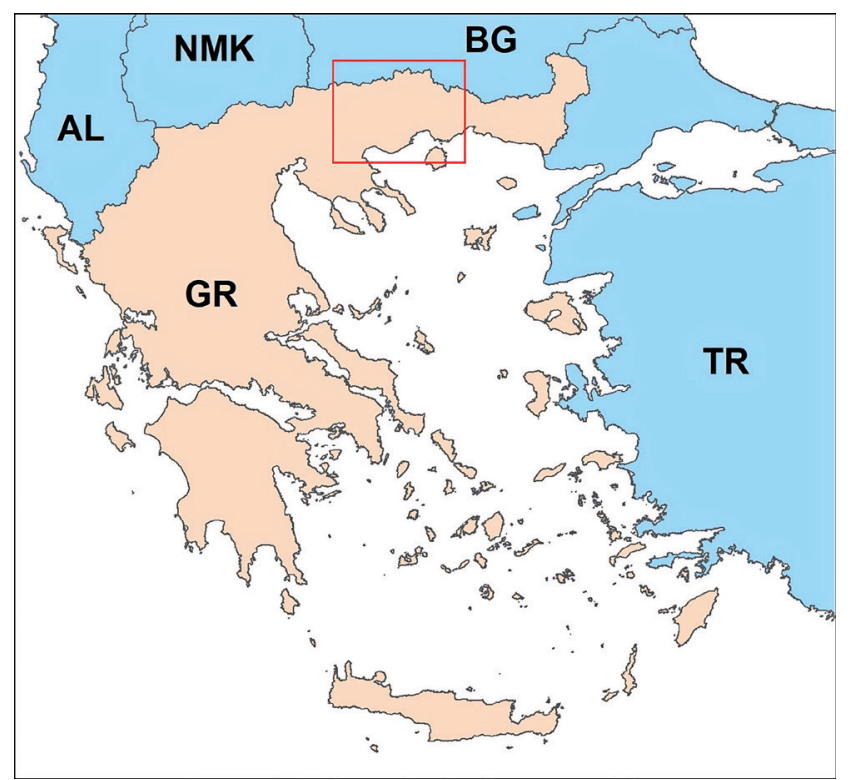

ra 2000 (Table 1). The network of these areas covers the summits and the high altitudinal zones of Mts Falakron, Pangeon, Menikion, Vrondous and Orvilos, four areas of Rodopi mountain range (Simyda, Elatia, Frakto, Koula), and a part of Nestos river (two SACs) (Fig. 2). Moreover, three other small-sized SACs include riparian areas in the lowlands (GR1260002, GR1260003 and GR1220003). The total area of these SACs is approximately $103,244.92$ $\mathrm{Ha}$ (Dafis et al. 1996).

East Macedonia, as most parts of Greece, presents a high variability of vegetation types (from maquis-pseudomaquis to Picea abies forests and subalpine grasslands) and the geological substrates (e.g. limestones, granites, schists). The combinations of these factors, together with the human impact observed during the last few decades, creates a mosaic of different habitats, where many orchids can occur (Tsiftsis et al. 2007; Tsiftsis and Antonopoulos 2017). Another factor that has a positive effect on the number of orchid taxa is the geographical position of the study area. As a part of northern Greece, which shares some common mountainous ranges with Bulgaria (e.g. Rodopi mountain range, Mt. Orvilos), the area hosts orchids of northern origin, some of which are endemic here (e.g. Neottia cordata; Tsiftsis et al. 2019).

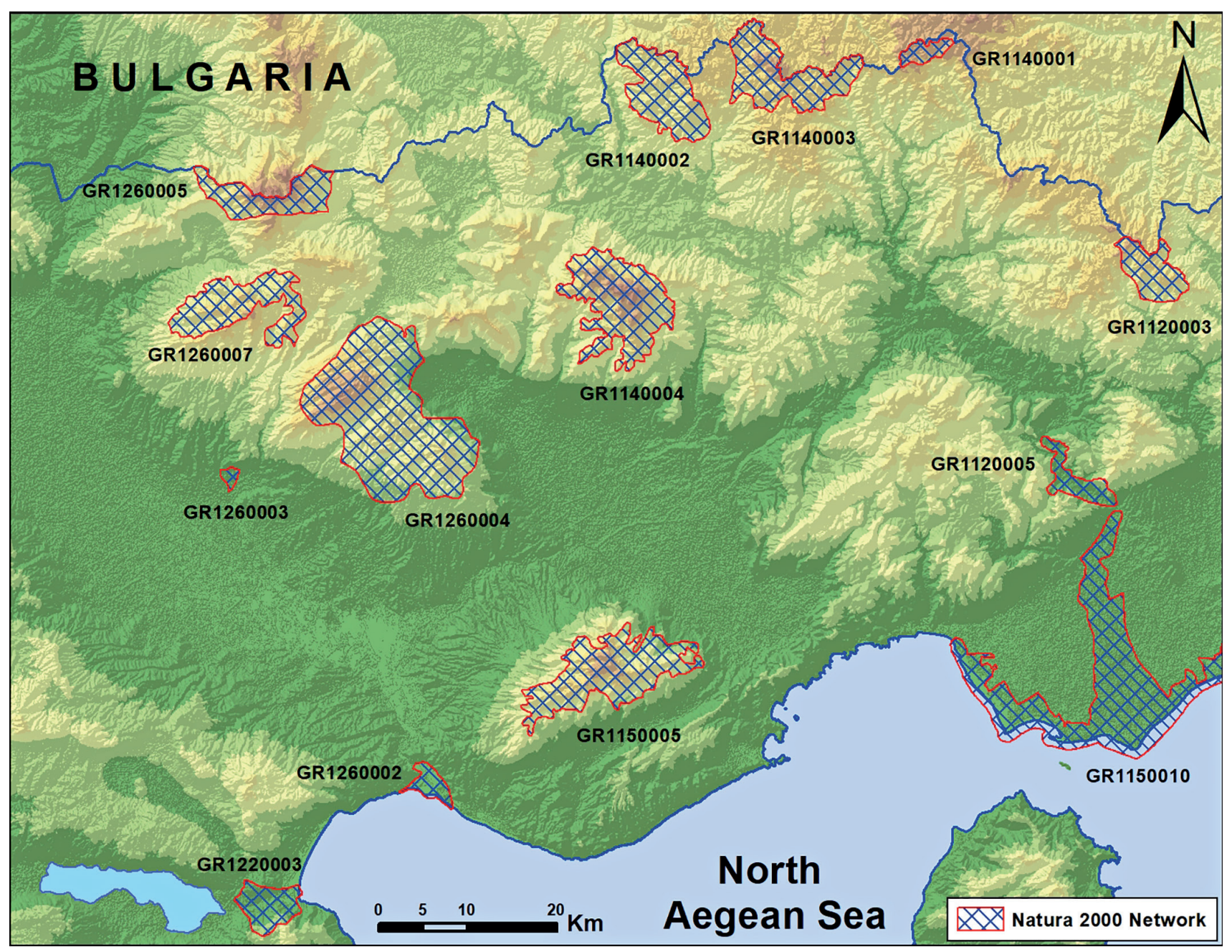

Fig. 2 Map of East Macedonia (NE Greece) (GR: Greece; AL: Albania, NMK: North Macedonia; BG: Bulgaria; TR: Turkey). The official names of the Special Areas of Conservation are presented in Table 1. 
The distribution data used for the analyses were based on the database that was built for the purposes of the Orchid Flora of Greece project (Tsiftsis and Antonopoulos 2017), which is still being updated with new orchid records based on recent literature cites and unpublished data (records made up to now). The nomenclature of the orchid taxa follows Dimopoulos et al. (2013), Antonopoulos and Tsiftsis (2017) and Tsiftsis and Antonopoulos (2017). In total, distribution data (8,788 records) of 73 orchid taxa occurring or being reported for the study area were used. Ophrys insectifera, recorded by Zaganiaris (1940), was excluded from the total number of orchids in East Macedonia, because this very old record has not been confirmed recently and could not be georeferenced with sufficient accuracy. To assess the effectiveness of the Natura 2000 network in conserving all the orchid taxa of the study, a $1 \times 1 \mathrm{~km}$ resolution Universal Transverse Mercator (UTM) grid was used in the analyses. Although the size of almost all grid cells was $1 \mathrm{~km}^{2}$, the size of a number of cells was different. Specifically, the grid cells that were adjacent to the Greek-Bulgarian borders, those close to the sea shoreline and close to the borders between different UTM coordinate zones (34T and 35T zones in the UTM projection) were of slightly different size.

The geographical coordinates of all orchid records were transformed into the UTM projection and then a matrix "species $\times$ grid cells" was generated. Afterwards, the grid cells that were totally within the Natura 2000 network, or of which more than half was included into the network, were characterized as grid cells of the Natura 2000 network. Thus, the grid cells with orchid occurrences in East Macedonia were divided into two categories: the Natura 2000 grid cells and the non-Natura 2000 grid cells. Based on this, the effectiveness of Natura 2000 in conserving the orchid flora in East Macedonia was assessed. To compare the number of orchids of the $1 \times 1 \mathrm{~km}$ grid cells inside and outside the Natura 2000 network, the Mann-Whitney U test was used.
To answer the second query, the chorological categories of the orchids of East Macedonia were adopted, as referred by Dimopoulos et al. (2013). For a few orchid taxa, not referred to by Dimopoulos et al. (2013), the chorological category was determined by taking into consideration their general distribution. The third query requires information about the threat categories of the Greek orchids, which were obtained from Tsiftsis and Tsiripidis (2016). One orchid taxon (Epipactis helleborine subsp. distans), not referred by Tsiftsis and Tsiripidis (2016), was evaluated at a regional scale using the IUCN Red List Criteria (IUCN 2012a) and the guidelines for application of IUCN Red List Criteria at a National Level (IUCN 2012b).

\section{Results}

Out of the 73 orchid taxa recorded in East Macedonia, 14 taxa are exclusively distributed outside of the Natura 2000 network. Orchid taxa absent within Natura 2000 network are mainly found in the southern and central part of Greece. Such orchids (e.g. Neotinea lactea, N. maculata, several Ophrys taxa, Serapias cordigera subsp. cordigera, S. parviflora) have been recorded in a large number of $1 \times 1 \mathrm{~km}$ grid cells in Greece, but their distribution in East Macedonia is very restricted (Table 2). Apart from these, two species - Epipactis pontica and Epipogium aphyllum - although found in high altitude areas of Mt. Rodopi, were found in areas outside the Natura 2000 network. The Mann-Whitney U test has shown that the $1 \times 1 \mathrm{~km}$ grid cells of the Natura 2000 network host more orchid taxa compared to the grid cells outside the Natura 2000 network $(\mathrm{p}<0.05)$.

In total, the orchid taxa of East Macedonia are classified into 15 chorological categories (Fig. 3; Table 2). Most of them belong to the European-SW Asian (20.55\%), Mediterranean (17.81\%) and Balkan (15.07\%) categories, followed by the Mediterranean-European taxa (12.33\%).

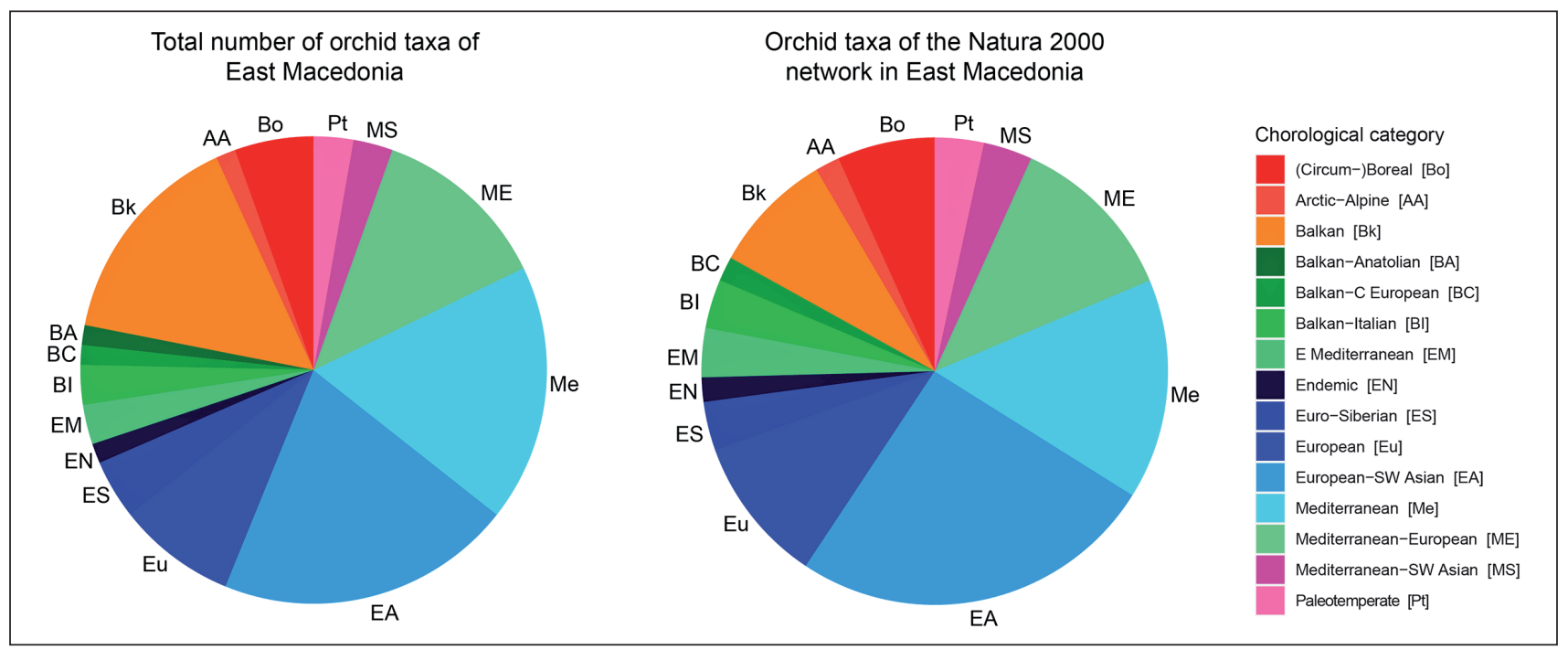

Fig. 3 Chorological spectrum of all orchid taxa recorded in East Macedonia (left graph) and of those recorded within the Natura 2000 network (right graph). 
Table 2 Orchid taxa recorded in East Macedonia, their chorological category and the number of $1 \times 1 \mathrm{~km}$ grid cells in which they have been recorded.

\begin{tabular}{|c|c|c|c|c|c|}
\hline Taxon & $\begin{array}{c}\text { Chorological } \\
\text { category }\end{array}$ & $\begin{array}{c}\text { IUCN } \\
\text { category }\end{array}$ & $\begin{array}{c}\text { Total number of } \\
1 \times 1 \mathrm{~km} \text { grid cells }\end{array}$ & $\begin{array}{c}1 \times 1 \text { km grid cells } \\
\text { within Natura } 2000 \\
\text { network }\end{array}$ & $\begin{array}{c}\text { Total number of } \\
1 \times 1 \mathrm{~km} \text { grid cells } \\
\text { in Greece }\end{array}$ \\
\hline Anacamptis coriophora subsp. coriophora & EA & & 18 & 2 & 137 \\
\hline Anacamptis coriophora subsp. fragrans & Me & & 69 & 18 & 2,212 \\
\hline Anacamptis laxiflora subsp. laxiflora & Me & & 32 & 11 & 1,703 \\
\hline Anacamptis morio subsp. caucasica & MS & & 378 & 46 & 2,389 \\
\hline Anacamptis palustris subsp. elegans & $\mathrm{BA}$ & $N T^{*}$ & 3 & 0 & 70 \\
\hline Anacamptis papilionacea subsp. papilionacea & MS & & 53 & 13 & 446 \\
\hline Anacamptis pyramidalis & $\mathrm{Eu}$ & & 253 & 41 & 4,121 \\
\hline Cephalanthera damasonium & ME & & 216 & 70 & 914 \\
\hline Cephalanthera longifolia & EA & & 202 & 47 & 1,033 \\
\hline Cephalanthera rubra & EA & & 214 & 66 & 1,130 \\
\hline Coeloglossum viride & Bo & & 43 & 35 & 80 \\
\hline Corallorhiza trifida & Bo & & 116 & 54 & 257 \\
\hline Dactylorhiza cordigera subsp. cordigera & Bk & & 44 & 22 & 122 \\
\hline Dactylorhiza incarnata & EA & $\mathrm{EN}^{*}$ & 8 & 4 & 13 \\
\hline Dactylorhiza macedonica & EN & $\mathrm{VU}^{*}$ & 17 & 8 & 40 \\
\hline Dactylorhiza romana & Me & & 21 & 4 & 448 \\
\hline Dactylorhiza saccifera & Me & & 41 & 21 & 862 \\
\hline Dactylorhiza sambucina & $\mathrm{Eu}$ & & 244 & 125 & 696 \\
\hline Epipactis atrorubens & EA & & 46 & 36 & 199 \\
\hline Epipactis helleborine subsp. distans & $\mathrm{Eu}$ & $\mathrm{EN}^{* *}$ & 3 & 3 & 5 \\
\hline Epipactis helleborine subsp. helleborine & $\mathrm{Pt}$ & & 371 & 145 & 1,317 \\
\hline Epipactis leptochila subsp. naousaensis & $\mathrm{BI}$ & $\mathrm{EN}^{*}$ & 7 & 6 & 40 \\
\hline Epipactis leptochila subsp. neglecta & $\mathrm{Eu}$ & $\mathrm{VU}^{*}$ & 6 & 3 & 7 \\
\hline Epipactis microphylla & EA & & 54 & 21 & 506 \\
\hline Epipactis palustris & EA & & 15 & 7 & 179 \\
\hline Epipactis persica subsp. exilis & $\mathrm{BI}$ & & 109 & 19 & 297 \\
\hline Epipactis pontica & ME & $N T^{*}$ & 8 & 0 & 12 \\
\hline Epipogium aphyllum & ES & & 5 & 0 & 48 \\
\hline Goodyera repens & Bo & & 61 & 38 & 65 \\
\hline Gymnadenia conopsea & EA & & 146 & 82 & 410 \\
\hline Gymnadenia frivaldii & Bk & $N T^{*}$ & 5 & 2 & 22 \\
\hline Gymnadenia odoratissima & $\mathrm{Eu}$ & $C R^{*}$ & 1 & 1 & 1 \\
\hline Gymnadenia rhellicani & $A A$ & $C R^{*}$ & 4 & 4 & 7 \\
\hline Himantoglossum jankae & $\mathrm{BC}$ & & 269 & 23 & 755 \\
\hline Limodorum abortivum & Me & & 146 & 18 & 1,708 \\
\hline Neotinea lactea & $\mathrm{Me}$ & & 1 & 0 & 931 \\
\hline Neotinea maculata & Me & & 2 & 0 & 1,467 \\
\hline Neotinea tridentata & Me & & 251 & 83 & 1,194 \\
\hline Neotinea ustulata & $\mathrm{Eu}$ & & 77 & 36 & 209 \\
\hline Neottia cordata & Bo & $\mathrm{VU}^{*}$ & 18 & 11 & 18 \\
\hline Neottia nidus-avis & EA & & 413 & 138 & 1,051 \\
\hline Neottia ovata & EA & & 90 & 13 & 487 \\
\hline Ophrys apifera & ME & & 27 & 3 & 798 \\
\hline
\end{tabular}




\begin{tabular}{|c|c|c|c|c|c|}
\hline Taxon & $\begin{array}{c}\text { Chorological } \\
\text { category }\end{array}$ & $\begin{array}{c}\text { IUCN } \\
\text { category }\end{array}$ & $\begin{array}{c}\text { Total number of } \\
1 \times 1 \mathrm{~km} \text { grid cells }\end{array}$ & $\begin{array}{c}1 \times 1 \mathrm{~km} \text { grid cells } \\
\text { within Natura } 2000 \\
\text { network }\end{array}$ & $\begin{array}{c}\text { Total number of } \\
1 \times 1 \mathrm{~km} \text { grid cells } \\
\text { in Greece }\end{array}$ \\
\hline Ophrys attica & $\mathrm{Bk}$ & & 1 & 0 & 556 \\
\hline Ophrys epirotica & $\mathrm{Bk}$ & & 12 & 0 & 442 \\
\hline Ophrys grammica & Bk & & 46 & 15 & 547 \\
\hline Ophrys hansreinhardii & $\mathrm{Bk}$ & & 2 & 1 & 43 \\
\hline Ophrys hebes & $\mathrm{Bk}$ & & 13 & 2 & 168 \\
\hline Ophrys helenae & Bk & & 1 & 0 & 518 \\
\hline Ophrys leucophthalma & $\mathrm{Bk}$ & & 1 & 0 & 71 \\
\hline Ophrys mammosa & ME & & 268 & 39 & 2,600 \\
\hline Ophrys oestrifera & $\mathrm{ME}$ & & 171 & 26 & 2,108 \\
\hline Ophrys reinhardiorum & $\mathrm{Bk}$ & & 1 & 0 & 34 \\
\hline Ophrys reinholdii & EM & & 8 & 4 & 475 \\
\hline Ophrys sicula & $\mathrm{ME}$ & & 1 & 0 & 5,502 \\
\hline Ophrys zeusii & Bk & & 11 & 0 & 125 \\
\hline Orchis italica & Me & & 70 & 9 & 2,770 \\
\hline Orchis mascula subsp. mascula & EA & & 155 & 72 & 976 \\
\hline Orchis militaris subsp. militaris & EA & $\mathrm{VU}^{*}$ & 10 & 9 & 13 \\
\hline Orchis pallens & ME & & 25 & 17 & 233 \\
\hline Orchis pauciflora & $\mathrm{Me}$ & & 11 & 4 & 660 \\
\hline Orchis provincialis & ME & & 7 & 4 & 836 \\
\hline Orchis purpurea subsp. purpurea & EA & & 122 & 20 & 474 \\
\hline Orchis quadripunctata & Me & & 59 & 29 & 2,002 \\
\hline Orchis simia subsp. simia & EA & & 53 & 13 & 616 \\
\hline Platanthera bifolia & $\mathrm{Pt}$ & & 24 & 6 & 145 \\
\hline Platanthera chlorantha subsp. chlorantha & ES & & 326 & 80 & 1,100 \\
\hline Pseudorchis albida & ES & $\mathrm{CR}^{*}$ & 1 & 1 & 1 \\
\hline Serapias bergonii & EM & & 13 & 1 & 3,515 \\
\hline Serapias cordigera subsp. cordigera & $\mathrm{Me}$ & & 2 & 0 & 212 \\
\hline Serapias parviflora & Me & & 1 & 0 & 1,056 \\
\hline Serapias vomeracea & ME & & 69 & 4 & 1,419 \\
\hline Spiranthes spiralis & EA & & 134 & 6 & 1,260 \\
\hline
\end{tabular}

CR: critically endangered; EN: endangered; VU: vulnerable; NT: near threatened

* Evaluation according to Tsiftsis and Tsiripidis (2016); ${ }^{* *}$ Evaluation based on recent distribution data and not by Tsiftsis and Tsiripidis (2016)

The categories with the smallest number of orchid taxa where the Balkan-Anatolian, Balkan-Central European, Arctic-Alpine and the Endemics, with one orchid taxon each. Similarly, in the total orchid flora of East Macedonia, the richest categories within the Natura 2000 network were the European-SW Asian taxa (25.42\%), the Mediterranean taxa (15.25\%) and the Mediterranean-European taxa (11.86\%). On the contrary, 6 Balkan and 4 Mediterranean orchid taxa have not been recorded within the Natura 2000 network.

Out of the 37 Greek orchid taxa that have been classified in the threat categories (Critically Endangered, Endangered and Vulnerable) of the International Union for the Conservation of Nature (IUCN), nine occur in East Macedonia (Table 2), whereas 3 out of 11 orchid taxa were classified as Near Threatened. One more taxon (Epipactis helleborine subsp. distans), is classified as Endangered (criterion D).

The three critically endangered taxa (Gymnadenia odoratissima, G. rhellicani, Pseudorchis albida) are either exclusively distributed in the Natura 2000 network, or have their highest populations there (Table 2). Among the endangered species, Dactylorhiza incarnata and Epipactis helleborine subsp. distans are mainly found in East Macedonia, whereas Epipactis leptochila subsp. naousaensis has some viable populations in the Natura 2000 network. From the vulnerable orchid taxa recorded in East Macedonia, two (Epipactis leptochila subsp. neglecta and Dactylorhiza macedonica) can be found elsewhere in Greece. Out of the areas where they have been recorded in East 
Macedonia, about one-half is within the Natura 2000 network. The other two orchids (Neottia cordata and Orchis militaris subsp. militaris) are almost exclusively distributed in East Macedonia with their larger distribution being within the Natura 2000 network of the area.

Another species category, whose species could not be classified in any of the three threat categories of the IUCN, is the category of the Near Threatened species. East Macedonia hosts three orchid taxa of this category (Anacamptis palustris subsp. elegans, Epipactis pontica and Gymnadenia frivaldii), from which only $G$. frivaldii is found within the Natura 2000 network (Table 2).

\section{Discussion}

As also stated in the introduction, the Natura 2000 network in Europe has been designed to ensure the longterm persistence of a large number of species (valuable and threatened) and habitats of European importance (European Commission 2020). Fourteen Special Areas of Conservation (SACs) of the Natura 2000 network have been established in East Macedonia (Table 1), aiming at the protection of the local flora and habitats (Dafis et al. 1996). Here I show that the Natura 2000 network fails to protect the total orchid flora in the area, because the distribution of 14 orchid taxa is not overlapping with any of the Special Areas of Conservation established in East Macedonia, similarly to Tsiftsis et al. (2009), whose results were based on fewer data, corresponding to a more restricted area. However, East Macedonia is not the only exception in this respect. Dimitrakopoulos et al. (2004), Tsiftsis et al. (2011) and Trigas et al. (2012) show that the spatial overlap of the Natura 2000 network with the important areas for the endemic species of the Peloponnese, the orchids of Crete and the plant biodiversity of Crete, respectively, was low in all cases.

Most orchid taxa that are not found within the Natura 2000 network in East Macedonia belong to the chorological category of the Balkan species, followed by the Mediterranean species. These Balkan species belong to the genus Ophrys and are mainly distributed in central and northwestern Greece (Antonopoulos and Tsiftsis 2017; Tsiftsis and Antonopoulos 2017), whereas Mediterranean species belong to the genera Serapias and Neotinea, with a wider distribution both in Greece and Europe (Delforge 2006; Kretzschmar et al. 2007). The most important part of the Natura 2000 network in East Macedonia exists in the high mountainous areas, characterized by cold climatic conditions and analogous to such climate vegetation. Orchid taxa preferring milder climatic conditions, such as several Balkan and Mediterranean species, cannot therefore be found in the high-altitude areas of East Macedonia. Species of these genera are disturbance-tolerant, widely distributed in open habitats at low or medium altitudes, where human activities are rather intense (Dafni 1987; Tsiftsis et al. 2019). Although such areas are not included in the Natura 2000 network, strict protection of the habitats where these orchid taxa occur might cause a reduction to their populations as the result of the natural vegetation succession.

Contrary to the orchid taxa mentioned above, Epipactis pontica is a Mediterranean-European taxon, whose most populations, and among them the largest ones in size, are distributed in East Macedonia. However, the sites where it has been recorded so far are not overlapping with the Natura 2000 network. This species is categorized as Near Threatened according to the classification of the IUCN, with the possibility to become Vulnerable or even Threatened under improper management (Tsiftsis and Tsiripidis 2016).

Anacamptis palustris subsp. elegans is another taxon, whose distribution in East Macedonia is not overlapping with the Natura 2000 network. It was recorded in several sites all around Greece (70 grid cells; Table 2), mostly in low or medium altitudes. A number of these sites has been severely degraded and its total populations greatly reduced during the last two decades.

A great advantage of the Natura 2000 network in East Macedonia is that the Special Areas of Conservation established here strongly overlap with the distribution of the IUCN red listed orchid taxa. Such orchids usually reach their southernmost distribution limits in northern Greece (e.g. Gymnadenia odoratissima, G. rhellicani, Neottia cordata, Pseudorchis albida) and their distribution is mainly driven by climate. Thus, these orchid taxa are sensitive to increasing temperatures and might be influenced by climate change (Kolanowska and Jakubska-Busse 2020).

Except of the high overlap between the distribution of the IUCN red listed orchids and the Natura 2000 network in East Macedonia, the higher number of orchid taxa per grid cell in the network compared to the grid cells outside it, is another advantage. The natural conditions of the Natura 2000 network create suitable circumstances for the existence of most orchid taxa. This confirms the design and the establishment of the Special Areas of Conservation in East Macedonia as this network offer, under suitable management actions, multiple possibilities for the future survival of such an important group of plant species.

\section{Conclusions}

Natura 2000 network established in East Macedonia hosts a significant number of orchids (59 out of the 73 orchid taxa). Among them, the distribution of almost all orchids of central and northern European origin (e.g. Coeloglossum viride, Dactylorhiza incarnata, Goodyera repens, Gymnadenia rhellicani, Neottia cordata, Orchis militaris subsp. militaris) and the distribution of those that have been classified in the threat categories of the IUCN is highly overlapped with the Special 
Areas of Conservation in East Macedonia. Although this demonstrates the significance of the Natura 2000 network in conserving the orchid taxa in East Macedonia, I have used only a small area of Greece. A similar study should be conducted for the whole of Greece.

\section{REFERENCES}

Antonopoulos Z, Tsiftsis S (2017) The Atlas of the Greek Orchids, Vol. II. Mediterraneo Editions, Rethymno.

Dafis S, Papastergiadou E, Georghiou K, Babalonas D, Georgiadis T, Papageorgiou M, Lazaridou T, Tsiaoussi V (1996) Directive 92/43. EEC The Greek "Habitat" project Natura 2000: an overview. The Goulandris Natural History Museum, Greek Biotope-Wetland Centre, Thessaloniki.

Dafni A (1987) Pollination in Orchis and related genera: evolution from reward to deception. In: Adritti J (ed) Orchid biology, reviews and perspectives, vol IV. Cornell University Press, Ithaca, pp 79-104.

Delforge P (2006) Orchids of Europe, North Africa and the Middle East. A and C Black Publishers Ltd., 3rd edition, London.

Dimitrakopoulos P, Memtsas D, Troumbis A (2004) Questioning the effectiveness of the Natura 2000 special areas of conservation strategy: The case of Crete. Glob Ecol Biogeogr 13: 199-207.

Dimopoulos P, Raus T, Bergmeier E, Constantinidis T, Iatrou G, Kokkini S, Strid A, Tzanoudakis D (2013) Vascular plants of Greece: An annotated checklist. Botanischer Garten und Botanisches Museum Berlin-Dahlem, Freie Universität Berlin; Hellenic Botanical Society, Athens. Englera 31: 1-370.

European Commission (2020) Natura 2000. https://ec.europa.eu /environment/nature/natura2000/index_en.htm

Geldmann J, Manica A, Burgess ND, Coad L, Balmford A (2019) A global-level assessment of the effectiveness of protected areas at resisting anthropogenic pressures. PNAS 116: 23209-23215.

González-Maya JF, Víquez-R LR, Belant JL, Ceballos G (2015) Effectiveness of protected areas for representing species and populations of terrestrial mammals in Costa Rica. PLoS ONE 10: $\mathrm{e} 0124480$

IUCN (2012a) IUCN Red List categories and criteria: Version 3.1. Second edition. IUCN Species Survival Commission. Gland, Switzerland and Cambridge, UK.

IUCN (2012b) Guidelines for application of IUCN Red List Criteria at regional and national levels: Version 4.0. Gland, Switzerland and Cambridge, UK.

Joppa L, Baillie J, Robinson JG (2016) Protected areas: are they safeguarding biodiversity? Wiley-Blackwell, London.
Kolanowska M, Jakubska-Busse A (2020) Is the lady's-slipper orchid (Cypripedium calceolus) likely to shortly become extinct in Europe? Insights based on ecological niche modelling. PLoS ONE 15: e0228420.

Kretzschmar H, Eccarius W, Dietrich H (2007) The orchid genera Anacamptis, Orchis and Neotinea. Phylogeny, Taxonomy, Morphology, Biology, Distribution, Ecology and Hybridisation. Bürgel.

Lafranchis T, Sfikas G (2009) Flowers of Greece, Vol. II. Diatheo, Paris.

Neugarten RA, Moull K, Acero Martinez N, Andriamaro L, Bernard C, Bonham C, ... Turner W (2020) Trends in protected area representation of biodiversity and ecosystem services in five tropical countries. Ecosyst Serv 42: 101078.

Rogalla von Bieberstein K, Sattout E, Christensen M, Pisupati B, Burgess ND, Harrison J, Geldmann J (2019) Improving collaboration in the implementation of global biodiversity conventions. Conserv Biol 33: 821-831.

Swarts ND, Dixon KW (2009) Terrestrial orchid conservation in the age of extinction. Ann Bot 104: 543-556.

Trigas P, Tsiftsis S, Tsiripidis I, Iatrou G (2012) Distribution patterns and conservation prioritization of the endemic flora of Peloponnese (Greece). Folia Geobot 47: 421-439.

Tsiftsis S, Antonopoulos Z (2011) Pseudorchis albida: an enigmatic orchid for the Greek flora. J Eur Orchid 43: 795-806.

Tsiftsis S, Antonopoulos Z (2017) The Atlas of the Greek Orchids, Vol. I. Mediterraneo Editions, Rethymno.

Tsiftsis S, Djordjević V, Tsiripidis I (2019) Neottia cordata (Orchidaceae) at its southernmost distribution border in Europe: Threat status and effectiveness of Natura 2000 Network for its conservation. J Nat Conserv 48: 27-35.

Tsiftsis S, Karagiannakidou V, Tsiripidis I (2007) The orchid flora of East Macedonia (NE Greece). J Eur Orchid 39: 489-526.

Tsiftsis S, Štípková Z, Kindlmann P (2019) Role of way of life, latitude, elevation and climate on the richness and distribution of orchid species. Biodivers Conserv 28: 75-96.

Tsiftsis S, Tsiripidis I (2016) Threat categories of the Greek orchids (Orchidaceae). Bot Chron 21: 43-74.

Tsiftsis S, Tsiripidis I, Karagiannakidou V (2009) Identifying areas of high importance for orchid conservation in east Macedonia (NE Greece). Biodivers Conserv 18: 1765-1780.

Tsiftsis S, Tsiripidis I, Trigas P (2011) Identifying important areas for orchid conservation in Crete. Eur J Environ Sci 1: 28-37.

Watson JEM, Evans MC, Carwardine J, Fuller RA, Joseph LN, Segan DB, Taylor MFJ, Fensham RJ, Possingham HP (2010) The capacity of Australia's protected-area system to represent threatened species. Conserv Biol 25: 324-332.

Zaganiaris DN (1940) Herbarium macedonicum. Tertium et quartum mille. Sci Ann Fac Phys Math. Aristotle University of Thessaloniki 6: 38-141. 